\title{
Jurist-Diction
}

Histori artikel: Submit 18 April 2019; Diterima 23 April 2019; Diterbitkan online 1 Mei 2019.

\section{Tanggungjawab Pelaku yang Mengikutsertakan Anak dalam Kegiatan Kampanye Politik}

\author{
Misbahul Amin \\ Misbahul.amin-2015@fh.unair.ac.id \\ Universitas Airlangga
}

\begin{abstract}
The object of a political campaign is the voter who has fulfilled the requirements as a voter in the General Election Law. General election participants during the political campaign has found using children in the context of political campaigns. Reports from the Indonesian Child Protection Commission are the proof that there is still frequent use of children in campaign activities by using various methods. The research method used in this research is normative juridical, using legal problem approach and conceptual approach. As for what will be discussed in this study is the qualification of the usage of children in political campaign activities according to the provisions of the Child Protection Act and the General Election Law. This research also discusses how is the criminal responsibility for political actors who use children in political campaign activities. This research concludes that the act of utilizing children in political campaign activities is against the law even though election participants argue that political campaigns are political education for children. It doesnt mean that political education for a children has to involved the children onto political campaigns, there are still various ways to educate a politics for a children rather than involved them directly onto the campaign. This study also concluded that the perpetrators who were proven to use children could be held to criminal responsibility as Article 87 of the Child Protection Act and Article 493 of the General Election Law.
\end{abstract}

Keywords: Child; Political Campaign; Criminal Sanctions; Criminal Responsibility.

\begin{abstract}
Abstrak
Objek dari kampanye politik adalah seorang pemilih dan telah memenuhi syarat sebagai pemilih sebagaimana Undang-Undang Pemilihan Umum. Peserta pemilu dalam pelaksanaan kampanye politik diketahui bahwa banyak yang mengikutsertakan anak dalam rangka kampanye politik. Laporan dari lembaga Komisi Perlindungan Anak Indonesia menjadi bukti bahwa masih sering terjadi mengikutsertakan anak dalam kegiatan kampanye dan menggunakan cara yang bermacammacam. Metode penelitian yang digunakan dalam penelitian ini adalah yuridis normatif, serta menggunakan pendekatan masalah perundang-undangan dan pendekatan konseptual. Adapun yang akan dibahas dalam penelitian ini adalah kualifikasi mengikutsertakan anak dalam kegiatan kampanye politik menurut ketentuan Undang-Undang Perlindungan Anak dan Undang-Undang Pemilihan Umum. Penelitian ini juga membahas bagaimana pertanggungjawaban pidana bagi pelaku yang mengikutsertakan anak dalam kegiatan kampanye politik. Penelitian ini menyimpulkan bahwa perbuatan mengikutsertakan anak dalam kegiatan kampanye politik merupakan perbuatan melawan hukum walaupun peserta pemilu berdalih kampanye politik merupakan pendidikan politik bagi anak. Pendidikan politik bagi anak tidak harus dilibatkan dalam kegiatan kampanye politik namun banyak cara untuk memberikan pendidikan politik bagi anak. Penelitian ini juga menyimpulkan bahwa pelaku yang terbukti mengikutsertakan anak dapat dimintai pertanggungjawaban pidana sebagaimana Pasal 87 Undang-Undang Perlindungan Anak dan Pasal 493 Undang-Undang Pemilihan Umum.
\end{abstract}

Kata Kunci: Anak; Kampanye Politik; Sanksi Pidana; Pertanggungjawaban Pidana. 


\section{Pendahuluan}

Indonesia sebagai negara hukum mengatur perlindungan terhadap warga negaranya, tak terkecuali perlindungan terhadap anak. Undang-Undang Dasar Negara Republik Indonesia 1945 mengakui tentang hak-hak dasar anak yaitu "Setiap anak berhak atas kelangsungan hidup, tumbuh, dan berkembang, serta berhak atas perlindungan dari kekerasan dan diskriminasi". ${ }^{1}$ Berdasarkan konvensi Internasional hak-hak anak, terdapat tiga prinsip dasar yang harus dijaga keseimbangannya baik anak. Prinsip pertama adalah kepentingan terbaik bagi anak, salah satunya mendapat perlindungan dari penyalahgunaan. Prinsip kedua adalah partisipasi yang bermakna mendengarkan pendapat-pendapat dari anak. Prinsip ketiga adalah bimbingan orang tua ataupun wali hukumnya yang dijalankan sesuai hak-hak anak serta tumbuh kembang anak. ${ }^{2}$

Perlindungan anak yang diatur dalam peraturan perundang-undangan telah mengatur secara keseluruhan terhadap perlindungan anak, dengan harapan perlindungan terhadap anak dapat terlaksana dengan baik. Perlindungan anak agar dapat berjalan dengan optimal maka perlindungan anak tersebut perlu dilaksanakan sedini mungkin, yakni sejak dari dalam kandungan. ${ }^{3}$ Perlindungan dari penelantaran, eksploitasi (ekonomi, tenaga, seksual) ataupun kekerasan.

Dewasa ini, walaupun perlindungan anak telah diatur dalam peraturan perundang-undangan namun masih terdapat pelanggaran-pelanggaran terhadap hak anak yang salah satunya adalah mengikutsertakan anak dalam kegiatan kampanye politik. Walaupun negara Indonesia merupakan negara demokrasi namun yang perlu diingat bahwa negara Indonesia merupakan negara hukum. Konsepsi negara hukum tersebut mengakomodir pula perlindungan terhadap hak-hak anak.

\footnotetext{
1 Yang dimaksud dengan UUD NRI 1945 adalah Undang-Undang Dasar hasil amandemen terakhir

2 Rika Lestari, “Tinjauan Yuridis Pelibatan Anak-Anak Dalam Penyelenggaraan Pemilu”, (Vol 2 No 01, 2008) $\leq$ https://ejournal.unri.ac.id/index.php/JK/article/view/447>accessed 1 Agustus 2018.

3 Imam Sukadi, "Tanggung Jawab Negara Terhadap Anak Terlantar dalam Operasionalisasi Pemerintah di Bidang Perlindungan Hak Anak", (Media Neliti 2013).[110]. < https://media. neliti.com/media/publications/23659-ID-tanggung-jawab-negara-terhadap-anak-terlantar-dalamoperasionalisasi-pemerintah.pdf $>$ accessed 2 Agustus 2018.
} 
Mengikutsertakan anak dalam kegiatan kampanye politik bukanlah perbuatan yang tepat karena anak memiliki hak untuk terbebas dari penyalahgunaan dari kegiatan politik. Berdasarkan data dari Komisi Perlindungan Anak Indonesia yang melakukan pengawasan terhadap kampanye politik yang dilakukan di tahun 2018 dan 2014 masih saja terdapat pihak yang melibatkan anak dalam kegiatan kampanye politik. Tahun 2018 berdasarkan data dari Komisi Perlindungan Anak Indonesia terdapat 15 jenis pelanggaran dan 34 kasus penyalahgunaan. Sedangkan pada tahun 2014 terdapat 248 kasus yang mengikutsertakan anak dalam kegiatan kampanye politik. ${ }^{4}$

Mengikutsertakan anak dalam kegiatan kampanye politik merupakan sebuah fenomena berulang setiap 5 tahun sekali atau setiap putaran kampanye. Anak tidak hanya diajak untuk menghadiri kegiatan orasi politik saja, namun juga ikut konvoi-konvoi yang seringkali ugal-ugalan dan tidak mengindahkan aturan lalu lintas. Terkadang terdapat anak juga yang membawa bendera ataupun atribut partai tertentu, selain itu juga ada anak yang mukanya di cat sesuai dengan warna pilihan partai yang didukung oleh keluarganya sehingga mereka tampak seperti supporter kecil yang sangar. ${ }^{5}$ Risiko yang dihadapi oleh anak tidak hanya masalah jasmani saja, namun permasalahan psikologis juga yang mana dampak psikologis dapat terbawa anak hingga dewasa sehingga melibatkan anak-anak merupakan tindakan berbahaya dan dapat dikatakan langkah yang kurang perhitungan. ${ }^{6}$

Orang tua yang beranggapan bahwa pelibatan anak dalam kegiatan kampanye politik merupakan bagian dari proses pendidikan politik dan pendidikan politik itu bagian dari proses demokratisasi. Memang benar, dalam Konvensi Hak-Hak Anak juga mengakui hak-hak anak untuk bersuara. Namun tampaknya orang tua belum menyadari jika melibatkan anak dalam kegiatan kampanye politik menimbulkan dampak yang merugikan bagi tumbuh kembang anak hingga pelanggaran terhadap

4 Dedi Hendrian, “KPAI Temukan Praktik Eksploitasi Anak Jelang Pilkada 2018”, http:// www.kpai.go.id/berita/kpai-temukan-praktik-eksploitasi-anak-jelang-pilkada-2018 accessed 3 Agustus 2018.

5 Sri Sanituti Hariadi dan Bagong Suyanto, Anak-Anak Yang Dilanggar Haknya”, (Lutfansah Mediatama 2001).[98].

6 ibid.[99]. 
hak-hak anak dan tindakan ini bukan merupakan tindakan yang dapat dibenarkan. Sedangkan kegiatan kampanye politik sendiri tidak ada yang dapat menjamin akan terlaksana dengan tertib maupun sesuai dengan prosedur karena kegiatan kampanye politik sendiri dihadiri massa yang banyak sehingga rentan terhadap bentrokan. ${ }^{7}$

Bentuk mengikutsertakan anak tersebut memiliki bentuk yang bermacammacam, ada yang menjadikan anak sebagai juru kampanye, memobilisasi massa anak, menampilkan anak diatas panggung kampanye politik, membawa anak dibawah 7 tahun ke arena kampanye dan lain-lain. Tidak tepatnya anak diikutsertakan dalam kegiatan kampanye politik karena dalam kegiatan kampanye politik sangat sarat akan nuansa persaingan. Kegiatan kampanye seringkali terdapat seranganserangan terhadap lawan politiknya, tidak jarang pula materi kampanye tersebut berisi materi-materi yang kebenarannya belum terbukti.

Ketentuan mengenai pelarangan mengikutsertakan anak dalam kegiatan kampanye politik telah tertuang dalam hukum positif Indonesia yakni dengan adanya Undang-Undang Nomor 07 Tahun 2017 Tentang Pemilihan Umum (untuk selanjutnya disebut UU Pemilu) dan Undang-Undang Nomor 35 Tahun 2014 Tentang Perubahan atas Undang-Undang Nomor 23 Tahun 2002 Tentang Perlindungan Anak (untuk selanjutnya disebut UU Perlindungan Anak).

\section{Metode Penelitian}

Metode penelitian yang digunakan dalam penelitian ini adalah Doctrinal Research. Pendekatan yang digunakan dalam penelitian ini adalah Pendekatan Perundang-undangan (Statute Approach) dan Pendekatan Konseptual (Conceptual Approach).

\section{Kualifikasi Mengikutsertakan Anak dalam Kegiatan Kampanye Politik}

Anak memiliki hak-hak yang harus dilindungi sebagaimana Menurut Konvensi Hak Anak terdapat empat bidang hak-hak anak yang harus dipenuhi yakni: ${ }^{8}$

\footnotetext{
7 ibid. [100].

8 Abu Huraerah, Child Abuse Kekerasan Terhadap Anak, (Nuansa 2007).[32].
} 
1. Hak atas kelangsungan hidup, berkaitan dengan keberlangsungan hidup dari anak seperti pelayanan kesehatan;

2. Hak untuk berkembang, hak untuk berkembang memiliki cakupan yang cukup luas seperti hak atas pendidikan, waktu luang, kebebasan berpikir, berkeyakinan dan beragama serta perlindungan khusus bagi anak cacat.

3. Hak perlindungan, perlindungan atas segala bentuk-bentuk eksploitasi maupun perlakuan sewenang-wenang;

4. Hak partisipasi, kebebasan hak untuk berkumpul, menyatakan pendapat serta pengambilan keputusan sendiri.

Empat bidang hak anak tersebut merupakan elemen dasar yang harus didapatkan oleh anak. Berdasarkan hak-hak anak Komisi Perlindungan Anak Indonesia (untuk selanjutnya disebut KPAI) mengeluarkan klasifikasi bentuk-bentuk mengikutsertakan anak yang dilarang, hal ini dikarenakan masih belum jelasnya bentuk mengikutsertakan apa saja yang dilarang. Berdasarkan KPAI bentuk-bentuk mengikutsertakan yang dilarang adalah sebagai berikut: ${ }^{9}$

1. Memanipulasi data anak yang belum berusia 17 tahun dan belum menikah agar bisa dijadikan sebagai pemilih;

2. Menggunakan tempat fasilitas anak seperti tempat penitipan anak atau tempat pendidikan anak;

3. Memobilisasi massa anak oleh partai politik atau pasangan calon;

4. Anak digunakan sebagai penganjur atau juru kampanye untuk memilih calon atau partai tertentu;

5. Menampilkan anak sebagai bintang utama dari suatu iklan politik;

6. Menampilkan anak di atas panggung kampanye dalam bentuk hiburan;

7. Menggunakan anak untuk memasang atribut-atribut pasangan calon atau partai;

8. Menggunakan anak untuk melakukan pembayaran kepada pemilih dewasa dalam praktik politik uang;

9. Mempersenjatai anak atau benda berbahaya tertentu yang membahayakan bagi anak maupun orang lain;

10. Memaksa, membujuk atau merayu anak untuk melakukan hal-hal yang dilarang selama kegiatan;

11. Membawa anak ke arena kampanye terbuka yang membahayakan anak;

12. Tindakan kekerasan (seperti kepala anak digunduli, tubuh disemprot/cat);

13. Melakukan tindakan diskriminatif berupa pengucilan, penghinaan, maupun intimidasi terhadap anak yang orang tuanya yang berbeda atau diduga pilihan politiknya;

9 Argadhia Aditama dan Lely Anna Puspa Sari, "Perlindungan Anak Dalam Negara Hukum Dan Demokrasi Melalui Pemilihan Umum Ramah Anak", http://www.academia.edu/6801080/ PERLINDUNGAN_HAK_ANAK DALAM_NEGARA_HUKUM_DAN_DEMOKRASI MELALUI_PEMILIHAN_UMUM_RAMAH_ANAK, accessed13 Oktober $201 \overline{8}$. 
14. Memprovokasi anak untuk membenci dan memusuhi; 15. Melibatkan anak dalam sengketa hasil perhitungan suara.

Berdasarkan bentuk-bentuk mengikutsertakan anak dalam kegiatan kampanye politik yang dibuat oleh KPAI, Muhammad Joni memberikan pendapatnya tentang tindakan mengikutsertakan anak yang dikatakan sebagai perbuatan penyalahgunaan anak yaitu: ${ }^{10}$

1. Eksploitasi terhadap anak;

2. Berbahaya bagi anak;

3. Mengikutsertakan secara salah;

4. Jangka waktu mengikutsertakan yang lama;

5. Menganjurkan untuk memilih salah satu partai maupun pasangan calon.

\section{Mengikutsertakan Anak dalam Kegiatan Kampanye Politik sebagai Perbuatan Pidana}

Bilamana berbicara mengenai tindak pidana maka hal yang perlu dipahami adalah apakah tindak pidana itu. Banyak sekali pengertian tindak pidana yang telah dipaparkan oleh para ahli, menurut Moeljatno tindak pidana adalah perbuatan oleh suatu aturan hukum dilarang dan diancam pidana, asal saja pada itu diingat bahwa larangan ditujukan kepada perbuatan dan ancaman pidananya ditujukan untuk orang yang menimbulkan kejadian itu. ${ }^{11}$

Selain itu Simons merumuskan juga mengenai unsur-unsur dari tindak pidana yaitu: ${ }^{12}$

1. Diancam dengan pidana oleh hukum;

2. Bertentangan dengan hukum;

3. Dilakukan oleh orang yang bersalah;

4. Orang itu dipandang bertanggung jawab atas perbuatannya.

Dalam tindak pidana juga terdapat cara-cara merumuskan suatu tindak pidana yaitu: ${ }^{13}$

${ }_{10}$ Muhammad Joni, "Penyalahgunaan Anak Dalam Kegiatan Politik", <http://www.mjoni. com/opini/perlindungan-anak/penyalahgunaan-anak-dalam-kegiatan-politik.html\#> accessed 4 Oktober 2018.

11 Moeljatno, Asas-Asas Hukum Pidana, (Rineka Cipta 2015).[59].

12 Andi Hamzah, Asas-Asas Hukum Pidana, (Rineka Cipta 2004).[88].

13 Didik Endro Purwoleksono, Hukum Pidana, (Airlangga University Press 2014).[45]. 
1. Menguraikan atau menyebutkan satu persatu dari unsur-unsur tindak pidana;

2. Hanya menyebut kualifikasi dari tindak pidana tanpa menguraikan unsurunsurnya;

3. Gabungan dari nomor 1 dan 2 .

Berdasarkan UU Pemilu diatur dalam Pasal 280 ayat (2) huruf k UU Pemilu mengatur bahwa "Pelaksana dan/atau Tim Kampanye dalam kegiatan Kampanye Pemilu dilarang mengikutsertakan Warga Negara Indonesia yang tidak memiliki hak memilih". Pada Pasal 1 angka 34 UU Pemilu menjelaskan kualifikasi pemilih, yaitu : "Pemilih adalah Warga Negara Indonesia yang sudah genap berumur 17 (tujuh belas) tahun atau lebih, sudah kawin, atau sudah pernah kawin”.

Berdasarkan redaksi pasal tersebut maka mempertegas bahwa anak tidak boleh diikutsertakan dalam kegiatan kampanye politik. Pelanggaran terhadap Pasal 280 ayat (2) dikatakan sebagai tindak pidana pemilu, hal ini juga dipertegas dengan adanya Pasal 280 ayat (4) yang berbunyi "Pelanggaran terhadap larangan ketentuan pada ayat (1) huruf c, huruff, huruf g, huruf I, dan hurufj, dan ayat (2) merupakan tindak pidana pemilu”.

Tindak pidana pemilu menurut Dedi Mulyadi dapat dibagi menjadi 2 kategori yaitu: ${ }^{14}$

1. Tindak pidana pemilu khusus adalah semua tindak pidana yang berkaitan dengan pemilu dan pada saat diselenggarakannya pemilu sebagaimana yang diatur dalam UU Pemilu.

2. Tindak pidana pemilu umum adalah semua tindak pidana yang berkaitan pemilu dan juga pada saat diselenggarakannya pemilu dan penyelesaiannya melalui Peradilan Umum.

Pembagian mengenai tindak pidana pemilu yang dipaparkan oleh Dedi Mulyadi dapat diketahui bahwa mengikutsertakan anak dalam kegiatan kampanye politik dikategorikan sebagai tindak pidana pemilu khusus. Mengikutsertakan anak dalam kegiatan kampanye politik termasuk dalam kategori tindak pidana pemilu khusus

${ }^{14}$ Dedi Mulyadi, Kebijakan Legislasi Tentang Sanksi Pidana Pemilu Legislatif Di Indonesia Dalam Perspektif Indonesia, (Gramata Publishing 2012).[418]. 
karena tindakan tersebut berkaitan dengan pemilu dan penyelesaiannya kasus tersebut dilakukan oleh majelis hakim khusus sebagaimana ketentuan yang ada pada UU Pemilu.

Dalam Peraturan Badan Pengawas Pemilu Nomor 26 Tahun 2018 Tentang Pengawasan Kampanye (untuk selanjutnya disebut Perbawaslu Pengawasan Pemilu) juga mengatur hal-hal yang dilarang dalam pelaksanaan kampanye. Pengatur hal-hal yang dilarang dalam pelaksanaan kampanye bertujuan untuk memastikan kegiatan kampanye dilakukan berdasarkan prinsip jujur, terbuka, dan dialogis, serta mengawasi pelaksanaan kegiatan Kampanye Pemilihan Umum sebagai perwujudan pendidikan politik sehingga perlu diatur mengenai mekanisme pengawasan kampanye.

Perbawaslu Pengawasan Pemilu ini secara garis besar mengatur hal-hal yang diatur juga dalam UU Pemilu. Perbedaannya, pada Perbawaslu Pengawasan Pemilu ini lebih mengatur secara teknis bagaimana pengawasan yang dilakukan oleh Bawaslu serta tugas Bawaslu sebagai badan yang mengawasi penyelenggaraan pemilu. Perbawaslu Pengawasan Pemilu tersebut secara garis besar sama dengan Pasal 280 ayat (2) UU Pemilu, hanya saja dalam Perbawaslu Pengawasan Pemilu ini menekankan tugas Bawaslu dari tingkat pusat hingga kabupaten/kota untuk memastikan Pelaksana dan/atau Tim tidak melibatkan orang-orang yang dilarang hadir dalam kegiatan kampanye. Perbawaslu ini melakukan penyebutan sebagai tindak pidana pemilu bilamana terjadi pelanggaran terhadap Pasal 6 ayat (2) Perbawaslu Pengawasan Pemilu hal ini dapat dilihat dalam Pasal 6 ayat (4) Perbawaslu Pengawasan Pemilu yang berbunyi "Pelanggaran terhadap larangan ketentuan pada ayat (1) huruf c, huruff, huruf g, huruf I, dan ayat (2) merupakan tindak pidana Pemilu”.

UU Perlindungan Anak mengatur pula tentang perlindungan anak dari penyalahgunaan dalam kegiatan politik yakni pada Pasal 15 hurufa UU Perlindungan Anak, karena UU Perlindungan Anak hakikatnya perlindungan terhadap korban anak. Perlindungan anak dalam UU Perlindungan Anak memiliki pengertian sebagaimana Pasal 1 angka 2 UU Perlindungan Anak yaitu "Perlindungan Anak 
adalah segala kegiatan untuk menjamin dan melindungi Anak dan hak-haknya agar dapat hidup, tumbuh, berkembang, dan berpartisipasi secara optimal sesuai dengan harkat dan martabat kemanusiaan, serta mendapat perlindungan dari kekerasan dan diskriminasi”. Redaksi Pasal tersebut menjelaskan perlindungan dari kekerasan, hal yang perlu dipahami bahwa kekerasan tidak hanya berupa kekerasan fisik saja. Kekerasan tersebut dapat berupa kekerasan secara fisik, psikis, seksual maupun secara sosial.

Dalam UU Perlindungan Anak, terutama ketentuan yang berkaitan dengan permasalahan mengikutsertakan anak dalam kegiatan kampanye politik tidak hanya pada Pasal 15 UU Perlindungan Anak saja. Bilamana ditelusuri lebih jauh sebenarnya terdapat ketentuan yang berkaitan dengan mengikutsertakan anak dalam kegiatan kampanye politik adalah Pasal 76H UU Perlindungan Anak. Pasal 76H UU Perlindungan Anak tersebut masuk dalam BAB XIA tentang larangan maka hal-hal yang terdapat pada BAB larangan ini merupakan dilarang oleh UU Perlindungan Anak. Redaksi Pasal 76H UU Perlindungan Anak tersebut berbunyi "Setiap orang dilarang merekrut atau memperalat Anak untuk kepentingan militer dan/atau lainnya dan membiarkan Anak tanpa perlindungan jiwa”.

Pasal 76H UU Perlindungan Anak terdapat redaksi “dan/atau lainnya”, untuk memaknai makna dari "lainnya" dapat dilakukan sebuah interpretasi terhadap bunyi pasal tersebut. Penjelasan pasalnya juga menerangkan bahwa pasal tersebut sudah cukup jelas. Bilamana terdapat pasal yang memiliki norma yang kabur maka dapat dilakukan penemuan hukum. Penemuan hukum yang dapat dilakukan terhadap pasal tersebut adalah dengan cara interpretasi secara sistematis. Pasal 76H UU Perlindungan Anak memiliki keterkaitan dengan Pasal 15 UU Perlindungan Anak, keterkaitan antara Pasal 76H dengan Pasal 15 UU Perlindungan Anak merupakan konsekuensi dari suatu undang-undang yang kesatuan secara sistematis dan saling terkait.

Dalam UU Perlindungan Anak ini mengatur unsur subjek yang lebih umum yakni "Setiap Orang", hal ini berbeda dengan UU Pemilu yang mengatur subjek yang lebih khusus yakni "Setiap Pelaksana dan/atau Tim Kampanye”. Perbedaan pengaturan unsur subjek terjadi karena perbedaan cikal bakal dari lahirnya undang- 
undang tersebut. UU Pemilu memiliki tujuan agar proses jalanya pemilihan umum dapat berjalan dengan lancar yang mana hal ini merupakan tanggungjawab dari setiap pelaksana dan/atau tim kampanye. Berbeda dengan UU Perlindungan Anak yang tujuannya melindungi korban anak, yang mana hal ini dilakukan oleh setiap orang agar anak dapat terlindungi. Dengan demikian, bagi setiap orang yang menyalahgunakan anak dalam kegiatan politik dapat dikenakan Pasal 76 H UU Perlindungan Anak.

\section{Pertanggungjawaban Pidana dalam Hukum Pidana}

Istilah tindak pidana dalam hukum pidana Indonesia merupakan terjemahan dari (Strafbaar Feit) dan dalam bahasa Inggris dari kata (Criminal Act). Pandangan dualisme terhadap (Strafbaar Feit) yakni tindak pidana dan pertanggungjawaban pidana. Pandangan dualisme tersebut dapat ditarik sebuah kesimpulan bahwa orang tidak melakukan tindak pidana pasti tidak dipidana, namun pelaku tindak pidana belum tentu dipidana. Pembahasan tentang pertanggungjawaban pidana berkaitan pula dengan dapat atau tidak dapat dipidanya seseorang pelaku. Dapat atau tidak dapatnya dipidana orang atau pelaku dapat dilihat dengan adanya asas kesalahan, asas kesalahan tersebut dikenal dengan adanya istilah (Geen Straf Zonder Schuld). (Geen Straf Zonder Schuld) memiliki arti bahwa tiada pidana tanpa kesalahan sehingga seseorang tidak dapat dipidana tanpa adanya unsur kesalahan terlebih dahulu. ${ }^{15}$ Berkaitan dengan pembahasan pertanggungjawaban pidana maka hal yang penting adalah: ${ }^{16}$

1. Unsur Kesalahan
a. Melakukan Tindak Pidana;
b. Diatas umur tertentu dan mampu bertanggungjawab;
c. Dengan kesengajaan atau kealpaan;
d. Tidak ada alasan pemaaf.

2. Bentuk kesalahan

a. Dengan kesengajaan.

\footnotetext{
${ }^{15}$ Didik Endro Purwoleksono, Op.Cit. [44].

16 ibid. [63].
} 
b. Dengan kealpaan.

Pertanggungjawaban pidana dapat dilakukan bilamana seorang pelaku tindak pidana telah melakukan suatu tindak pidana. Selain melakukan suatu tindak pidana, perbuatan tersebut memiliki suatu unsur melawan hukum. Untuk dilakukan pertanggungjawaban setidaknya terdapat 3 unsur yang dipenuhi, yaitu: ${ }^{17}$

1. Kemampuan bertanggungjawab;

2. Adanya kesalahan;

3. Tidak adanya alasan pemaaf.

Berdasarkan 3 unsur tersebut, unsur yang pertama yang harus dipenuhi adalah unsur kemampuan bertanggungjawab. Namun, terdapat kondisi tertentu yang menyebabkan tidak memiliki kemampuan untuk bertanggungjawab. Kondisi tidak mampubertanggungjawab tersebut dapat dicontohkan sepertikeadaanjiwa seseorang tidak normal dan fungsi otaknya tidak dapat bekerja secara normal maka orang tersebut termasuk kualifikasi dalam tidak memiliki kemampuan bertanggungjawab. Tidak memiliki kemampuan bertanggungjawab dikarenakan orang tersebut tidak tahu mana tindakan yang baik dan mana tindakan yang buruk. KUHP mengatur pula kondisi tertentu yang mana seseorang tidak memiliki kemampuan bertanggungjawab, hal ini terdapat pada Pasal 44 ayat (1) KUHP yang berbunyi "Barang siapa melakukan perbuatan yang tidak dapat dipertanggungjawabkan kepadanya, disebabkan karena jiwanya cacat dalam tubuhnya atau terganggu karena penyakit, tidak dipidana". Bilamana terdapat seseorang yang sakit jiwa dan melakukan tindak pidana pembunuhan maka orang tersebut tidak dapat dipidana dan dimasukkan ke Rumah Sakit Jiwa.

Menurut Didik Endro Purwoleksono seseorang yang dinyatakan mampu bertanggungjawab yaitu: ${ }^{18}$

1. Mampu menentukan niat, kehendak, rencana atas perbuatan yang akan dilakukan;

2. Mengetahui atau menginsafi bahwa perbuatannya tersebut dipandang tidak patut

${ }^{17}$ Amir Ilyas, Asas-Asas Hukum Pidana Memahami Tindak Pidana dan Pertanggungjawban Pidana Sebagai Syarat Pemidanaan, (Mahakarya Rangkang Offset Yogyakarta 2012).[75].

${ }^{18}$ Didik Endro Purwoleksono, Op.Cit.[68]. 
oleh masyarakat;

3. Mengetahui atau menginsafi arti, makna, hakikat dari baik atau buruk perbuatannya.

Unsur mampu bertanggungjawab merupakan unsur yang pertama, kemudian yang perlu diperhatikan adalah unsur kesalahan sebagaimana asas yang telah disebutkan yakni (Geen Straf Zonder Schuld). Terdapat beberapa ahli yang merumuskan mengenai unsur kesalahan, salah satunya adalah Moeljatno. Moeljatno berpendapat bahwa seseorang dikatakan mempunyai kesalahan apabila perbuatan pidana yang dilakukan pada waktu itu dianggap menyimpang dan tercela oleh masyarakat padahal orang tersebut mengetahui bahwa perbuatan tersebut dapat dihindari akan tetapi orang itu tetap melakukannya. ${ }^{19}$ Moeljatno juga memberikan beberapa unsur-unsur dalam adanya suatu kesalahan, yaitu: ${ }^{20}$

1. Terdakwa harus melakukan perbuatan pidana yang bersifat melawan hukum;

2. Di atas umur tertentu mampu bertanggungjawab;

3. Bahwa terdakwa mempunyai suatu bentuk kesalahan yang berupa kesengajaan ataupun kesalahan;

4. Tidak adanya suatu alasan pemaaf.

Pembahasan mengenai pertanggungjawaban pidana berkaitan dengan suatu kesalahan. Dalam kesalahan tersebut terdapat bentuk-bentuk dari kesalahan. Bentuk-bentuk dari kesalahan, yaitu: ${ }^{21}$

1. Kesengajaan sebagai maksud (Dolus Als Oogmerk)

Kesengajaan sebagai maksud ini memiliki makna bahwa kesengajaan sebagai maksud ini sebagai tujuan. Pelaku dalam kesengajaan sebagai maksud ini memang berkehendak atau memiliki tujuan untuk melakukan tindak pidana tersebut.

2. Kesengajaan sebagai kepastian (Zekerheids Bewustzijn)

Kesengajaan sebagai kepastian yakni berupa kesadaran secara akal manusia yang pada umumnya akan terjadi akibatnya dikarenakan suatu perbuatan

\footnotetext{
${ }^{19}$ Moeljatno, Op.Cit.[169].

${ }^{20}$ ibid.[177].

21 Didik Endro, Op.Cit.[70].
} 
tertentu dan akibatnya tidak dapat dihindari. Akibat yang timbul merupakan akibat lain dari tindakan yang dilakukannya bukan akibat yang dikehendaki. ${ }^{22}$

3. Kesengajaan sebagai kemungkinan (Dolus Eventualis)

Kesengajaan sebagai kemungkinan (Dolus Eventualis) juga dikenal sebagai teori apa boleh buat, hal ini dikarenakan bahwa pelaku tindak pidana mengetahui dan berkehendak melakukan tindak pidana, dan siapa yang menjadi korbannya pelaku tidak peduli.

Kesalahan sebagai bentuk kesengajaan terdapat lagi pembagian berdasarkan teori kehendak (wilstheorie) dan teori pengetahuan (voorstellingtheorie). Teori kehendak (wilstheorie) adalah kehendak yang diarahkan kepada terwujudnya perbuatan seperti apa yang ada dan telah dirumuskan di dalam peraturan perundang-undangan. Sedangkan teori pengetahuan (voorstellingtheorie) sebagai bentuk kesengajaan adalah kehendak untuk berbuat dengan mengetahui unsur-unsur yang diperlukan sebagaimana menurut rumusan perundang-undangan..$^{23}$

Bentuk kesalahan selain kesengajaan terdapat juga bentuk kesalahan kealpaan (Culpa). Kealpaan sendiri diakibatkan karena terdapatnya kurang berhati-hati dan tidak menduga-duga sehingga timbul suatu akibat yang tidak disengaja. Selain memiliki perbedaan antara kesengajaan dengan kealpaan, juga terdapat persamaan unsur antara dua bentuk atau corak kesalahan tersebut, yaitu: ${ }^{24}$

1. Adanya tindak pidana;

2. Di atas umur tertentu dan adanya kemampuan bertanggungjawab;

3. Tidak adanya alasan pemaaf;

4. Sehingga sama-sama diancam dengan pidana.

Beberapa sarjana banyak yang memberikan pandangan tentang kealpaan, dari beberapa pandangan sarjana dapat diambil 2 unsur dari kealpaan, yaitu: ${ }^{25}$

1. Kurang hati-hati

Kurang hati-hati bermakna bahwa pelaku tidak melakukan upaya pencegahan

${ }^{22}$ A. Fuad dan Tongat, Pengantar Hukum Pidana, (UMM Press 2004).[81].

${ }^{23}$ P.A.F. Lamintang dan Franciscus Theojunior Lamintang, Dasar Dasar Hukum Pidana Di Indonesia, (Sinar Grafika 2014).[314].

${ }^{24}$ Didik Endro, Op.Cit.[73].

25 ibid.[74]. 
ataupun tidak memiliki kemahiran dalam keadaan tertentu atau dalam caranya melakukan suatu perbuatan.

2. Kurang penduga-duga

a. Kealpaan yang disadari (Bewuste Culpa)

Kealpaan yang disadari memiliki bahwa pelaku menyadari akibat ataupun risiko dari tindakan pelaku tersebut.

b. Kealpaan yang tidak disadari (Onbewuste Culpa)

Kealpaan yang tidak disadari memiliki makna bahwa pelaku sedari awal memang tidak menyadari akibat dari suatu perbuatan akan terjadi, namun ternyata dalam perkembangannya justru akibat telah terjadi.

Tidak adanya suatu alasan pemaaf merupakan salah satu unsur kesalahan. Alasan pemaaf memiliki arti bahwa alasan yang menghapus kesalahan terdakwa, terhapusnya kesalahan terdakwa tetap dianggap sebagai perbuatan pidana namun tidak dapat dipidana karena tidak ada kesalahan.26 Roeslan saleh membedakan antara alasan pemaaf (menghapus unsur kesalahan) dan alasan pembenar (menghapus sifat melawan hukumnya). Suatu alasan pembenar itu meniadakan perbuatan pidana itu sendiri, sedangkan alasan pemaaf perbuatan pidananya masih ada, namun terdakwa tidak dapat di pidananya karena unsur kesalahannya tidak ada. ${ }^{27}$ Adanya pembedaan antara alasan pemaaf dan pembenar tersebut karena terdapat (moral force) yang berbeda terhadap kedua pembelaan tersebut. ${ }^{28}$

\section{Pertanggungjawaban Pidana terhadap Pelaku yang Mengikutsertakan Anak Dalam Kegiatan Kampanye Politik}

Unsur subjek yang mengatur dalam UU Pemilu dan UU Perlindungan Anak terdapat perbedaan. Hal ini juga berpengaruh pada subjek yang dapat dipertanggungjawabkan. UU Pemilu bilamana melanggar dengan mengikutsertakan

\footnotetext{
26 ibid, [76].

27 Roeslan Saleh, Daja Memaksa Dalam Hukum Pidana, (Yayasan Badan Penerbit Gadjah Mada 1957).[13].

${ }^{28}$ Chairul Huda, Dari Tiada Pidana Tanpa Kesalahan Menuju Kepada Tiada Pertanggungjawaban Pidana Tanpa Kesalahan, (Kencana 2006).[124].
} 
anak dalam kegiatan kampanye politik maka dapat dikenakan Pasal 493 UU Pemilu berbunyi "Setiap pelaksana dan/atau tim Kampanye Pemilu yang melanggar larangan sebagaimana dimaksud Pasal 280 ayat (2) dipidana dengan pidana kurungan paling lama 1 (satu) tahun dan denda paling banyak Rp12.000.000,00 (dua belas juta rupiah)". Pelaksana Kampanye dan Tim Kampanye secara garis besar memiliki kemiripan pengertian namun sebenarnya terdapat perbedaan dari pengertian tersebut. Jika Tim Kampanye merupakan satu kesatuan tim dari beberapa gabungan Partai Politik dan tim tersebut didaftarkan ke KPU, sedangkan Pelaksana Kampanye merupakan pihak yang terlibat dalam pelaksanaan kegiatan kampanye pemilu yang ditunjuk oleh Peserta Pemilu.

Pada UU Pemilu terdapat pula sanksi tindakan yang dapat diberikan oleh KPU bagi pelaksana kampanye yang melanggar Pasal 280 UU Pemilu, dalam hal ini termasuk pula bagi pelaksana kampanye dan/atau tim kampanye yang mengikutsertakan warga negara yang tidak memiliki hak memilih. Pengaturan tersebut terdapat pada Pasal 285 UU Pemilu yang berbunyi:

"Putusan pengadilan yang telah memperoleh kekuatan hukum tetap terhadap pelanggaran sebagaimana dimaksud dalam Pasal 280 dan Pasal 284 yang dikenai kepada pelaksana Kampanye Pemilu anggota DPR, DPD, DPRD provinsi, dan DPRD kabupaten/kota yang berstatus sebagai calon anggota DPR, DPD, DPRD provinsi, dan DPRD kabupaten/kota digunakan sebagai dasar KPU, KPU Provinsi, dan KPU Kabupaten/Kota untuk mengambil tindakan berupa:

a. Pembatalan nama calon anggota DPR, DPD, DPRD provinsi, dan DPRD kabupaten/kota dari daftar calon tetap; atau

b. Pembatalan penetapan calon anggota DPR, DPD, DPRD provinsi, dan DPRD kabupaten/kota sebagai calon terpilih"

Pemberian tindakan oleh KPU terhadap pelanggaran yang terdapat pada Pasal 280 UU Pemilu tidak dapat serta merta dilaksanakan. Pemberian tindakan tersebut dapat syarat yang harus dipenuhi terlebih dahulu. Syarat dilakukannya pemberian tindakan oleh KPU bilamana telah ada putusan pengadilan yang telah memperoleh kekuatan hukum tetap terhadap pelanggaran Pasal 280 UU Pemilu terlebih dahulu. Bilamana belum ada putusan hakim yang telah berkekuatan hukum tetap maka tindakan tersebut tidak dapat dilaksanakan oleh KPU. 
Bilamana pelaku yang mengikutsertakan anak dalam kegiatan kampanye politik bukan merupakan sebagai "Pelaksana dan/atau Tim Kampanye" maka undang-undang yang dapat digunakan adalah UU Perlindungan Anak. Pelaku yang dikenakan adalah sebagaimana Pasal 76H UU Perlindungan Anak setiap orang. Pertanggungjawaban setiap orang dalam Pasal 76H UU Perlindungan Anak diatur dalam Pasal 87 UU Perlindungan anak yang berbunyi, yaitu: ”Setiap Orang yang melanggar ketentuan sebagaimana dimaksud alam Pasal $76 \mathrm{H}$ dipidana dengan penjara paling lama 5 (lima) tahun dan/atau denda paling banyak Rp100.000.00,00 (serratus juta rupiah)". Dengan demikian, bilamana terdapat setiap orang yang mengikutsertakan anak dalam kegiatan kampanye politik maka dapat dikenakan Pasal 87 UU Perlindungan Anak, termasuk orang tua dari anak bilamana terbukti mengikutsertakan anak dalam kegiatan kampanye politik.

\section{Kesimpulan}

Mengikutsertakan anak dalam kegiatan kampanye politik dapat dikatakan sebagai perbuatan pidana karena hal ini melanggar ketentuan sebagaimana Pasal 280 ayat (2) UU Pemilu. Subjek yang dilarang mengikutsertakan adalah Pelaksana dan/atau Tim Kampanye, karena Pelaksana dan/atau Tim Kampanye pihak yang bertanggungjawab atas berjalannya pemilihan umum tersebut. Pasal $76 \mathrm{H} \mathrm{UU}$ Perlindungan Anak mengatur tentang pelarangan penyalahgunaan anak dalam kegiatan politik, namun subjek yang dapat dikenakan lebih luas yakni setiap orang. Setiap orang dalam hal ini siapa saja yang terbukti menyalahgunakan anak dalam kegiatan politik, termasuk pula orang tua anak.

Pelaku yang terbukti mengikutsertakan anak dalam kegiatan kampanye politik dapat dimintai pertanggungjawaban pidana sesuai Pasal 493 UU Pemilu yang mengatur bahwa bilamana setiap Pelaksana dan/atau Tim Kampanye yang terbukti melakukan mengikutsertakan anak dalam kegiatan kampanye politik dapat dikenakan kurungan paling lama satu tahun dan denda paling banyak Rp. 12.000.000,00. Pengaturan dalam UU Pemilu berkaitan dengan tindak pidana pemilu sehingga yang dijadikan subjek adalah Pelaksana dan/atau Tim Kampanye. 
Dalam UU Pemilu dikenal berupa tindakan oleh KPU bilamana terbukti melakukan mengikutsertakan anak dalam kegiatan kampanye, namun hal ini dapat dilakukan bilamana telah ada putusan pengadilan yang berkekuatan hukum tetap. Bagi pelaku yang bukan sebagai Pelaksana dan/atau Tim Kampanye dapat dikenakan Pasal 87 UU Perlindungan Anak bagi setiap orang yang melakukan mengikutsertakan anak dalam kegiatan kampanye politik dapat dikenai pidana penjara paling lama 15 tahun dan denda paling banyak Rp. 100.000.000,00.

\section{Daftar Bacaan}

\section{Buku}

Abu Huraerah, Child Abuse Kekerasan Terhadap Anak, (Nuansa 2007).

Amir Ilyas, Asas-Asas Hukum Pidana Memahami Tindak Pidana dan Pertanggungjawaban Pidana Sebagai Syarat Pemidanaan (Mahakarya Rangkang Offset 2012).

Andi Hamzah, Asas-Asas Hukum Pidana (Rineka Cipta 2004).

Arief Gosita, Masalah Korban Kejahatan Kumpulan Karangan (Akademika Pressindo 1993).

Bambang Waluyo, Viktimologi Perlindungan Hukum Terhadap Korban Kejahatan (Sinar Grafika 2011).

Dan Nimmo, Komunikasi Politik: Komunikator (Pesan dan Media 2009).

Dedi Mulyadi, Kebijakan Legislasi Tetntang Sanksi Pidana Pemilu Legislatif Di Indonesia Dalam Perspektif Indonesia (Gramata Publishing 2012).

Didik Endro Purwoleksono, Hukum Pidana (Airlanga Univesity Press 2014).

Moeljatno, Asas-Asas Hukum Pidana (Rineka Cipta 2015).

Muhadar, Viktimisasi Kejahatan Pertanahan (LaksBang PRESSindo 2006).

P.A.F Lamintang dan Franciscus Theojunior Lamintang., Dasar Dasar Hukum Pidana Di Indonesia (Sinar Grafika 2014).

Sri Sanituti Hariadi dan Bagong Suyanto, Anak-Anak Yang Dilanggar Haknya (Lutfansah Mediatama 2001). 
Topo Santoso, Tindak Pidana Pemilu (Sinar Grafika 2006).

\section{Jurnal}

Fauzan Ali Rasyid, "Kampanye Politik dan Persoalan Bangsa”, Mimbar, 2009.

Meta Suriyani, "Pertentangan Asas Perundang-undangan dalam Pengaturan Larangan Mobilisasi Anak pada Kampanye Pemilu", Jurnal Konstitusi, 2016.

\section{Skripsi}

Anugerah Indra Permana, "Restorative Justice Dalam Rangka Pemulihan Anak Pecandu Narkotika”, Skripsi, Fakultas Hukum Universitas Airlangga, 2017.

Faridha Tasya Hanafiah, "Pertanggungjawaban Pidana Pelaku Yang Mengedarkan Kosmetik Mengandung Bahan Berbahaya", Skripsi, Fakultas Hukum Universitas Airlangga, 2017.

\section{Laman}

Argadhia Aditama dan Lely Anna Puspa Sari, "Perlindungan Anak Dalam Negara Hukum Dan Demokrasi Melalui Pemilihan Umum Ramah Anak",(2018)< http://www.academia.edu/6801080/PERLINDUNGAN_HAK ANAK DALAM_NEGARA_HUKUM_DAN_DEMOKRASI_MELALUI PEMILIHAN_UMUM_RAMAH_ANAK,> accessed 13 Oktober 2018.

Imam Sukadi, "Tanggung Jawab Negara Terhadap Anak Terlantar dalam Operasionalisasi Pemerintah di Bidang Perlindungan Hak Anak", (media neliti, 2013) $\quad<$ https://media.neliti.com/media/publications/23659-IDtanggung-jawab-negara-terhadap-anak-terlantar-dalam-operasionalisasipemerintah.pdf $>$ accessed 2 Agustus 2018.

Muhammad Joni "Penyalahgunaan Anak Dalam Kegiatan Politik", <http://www. mjoni.com/opini/perlindungan-anak/penyalahgunaan-anak-dalam-kegiatanpolitik.html\#, > accessed 4 Oktober 2018.

Rika Lestari "Tinjauan Yuridis Pelibatan Anak-Anak Dalam Penyelenggaraan Pemilu", (Unri, 2008) <https://ejournal.unri.ac.id/index.php/JK/article/ view/47>, accessed 1 Agustus 2018.

\section{Perundang-undangan}

Undang-Undang Dasar Negara Republik Indonesia Tahun 1945. 
Undang-Undang Republik Indonesia Nomor 35 Tahun 2014 Tentang Perubahan atas Undang-Undang Nomor 23 Tahun 2002 Tentang Perlindungan Anak. (Lembaran Negara Republik Indonesia Tahun 2014 Nomor 297. Tambahan Lembaran Negara Republik Indonesia Nomor 5608).

Undang-Undang Republik Indonesia Nomor 07 Tahun 2017 Tentang Pemilihan Umum. (Lembaran Negara Republik Indonesia Tahun 2017 Nomor 182. Tambahan Lembaran Negara Republik Indonesia Nomor 6109).

Peraturan Badan Pengawas Pemilu Nomor 26 Tahun 2018 Tentang Pengawasan Kampanye Pemilihan Umum. (Berita Negara Republik Indonesia Tahun 2018 Nomor 1281).

Peraturan Komisi Pemilihan Umum Nomor 23 Tahun 2018 Tentang Kampanye Pemilihan Umum. (Berita Negara Republik Indonesia Nomor 973).

HOW TO CITE: Misbahul Amin, ‘Tanggungjawab Pelaku yang Mengikutsertakan Anak dalam Kegiatan Kampanye Politik’ (2019) Vol. 3 No. 2 Jurist-Diction. 
--halaman ini sengaja dibiarkan kosong-- 